\title{
AS NORMAS GERAIS DE DIREITO URBANÍSTICO
}

\author{
RICARDO MARCONDES MARTINS
}

1. Introdução. 2. Normas Gerais de Direito Urbanístico. 2.1 A competência concorrente da Uniāo e dos Estados para legislar sobre Direito urbanístico: artigo 24, I, da Constituição. 2.2 A doutrina de Geraldo Ataliba sobre normas gerais. 2.3 A doutrina de Diogo Figueiredo Moreira Neto sobre normas gerais. $2.4 O$ conceito de principios juridicos. 2.5 Elemento formal do conceito de normas gerais. 2.6 Elemento material do conceito de normas gerais. 2.7. As normas gerais de Direito urbanistico e as competências privativas dos Estados e dos Municípios. 2.8 As três espécies de normas gerais federais de Direito urbanístico. 2.9 A competência concorrente da União e dos Municípios para editar normas de Direito urbanístico diretamente vinculadas ao interesse local. 2.10 Normas gerais de Direito urbanístico de primeiro nível. 2.11 Normas gerais de Direito urbanistico de segundo nivel. 2.12 Panorama geral das competências legiferantes urbanísticas. 3. Conclusões. Referências Bibliográficas.

\section{Introdução}

O ordenamento jurídico brasileiro adotou como forma de Estado a Federação, expressamente consagrada-a no caput do artigo $1^{\circ}$ da Constituição Federal. $\mathrm{O}$ princípio federativo, além de estar enunciado logo no primeiro artigo e concretizado ao longo do texto através de uma série de subprincípios e regras, foi, nos incisos II e VII, letra "c", do artigo 34, elevado a princípio sensível e no $\$ 4^{\circ}$ do artigo 60 , a cláusula pétrea. Por força disso é tomado como um dos princípios de maior importância do ordenamento jurídico, seu alicerce maior, sua viga mestra. ${ }^{1}$ Pelo artigo 18

I Na classificação de Canotilho trata-se, sem sombra de dúvida, de princípio estruturante. CANOTILHO, J. J. Gomes. Direito Constitucional e Teoria da Constituição. 4. ed., Coimbra: Almedina. 2000, p. 1.137 et seq. O saudoso Professor Geraldo Ataliba era enfático: "no Brasil, os 
da Lei Maior, a Federação Brasileira compreende a União, os Estados. o Distrito Federal e os Municípios, todos autônomos. ${ }^{2} \mathrm{O}$ asseguramento dessa autonomia tem como pressuposto a discriminação das competências de cada entidade numa Constituição rígida. ${ }^{3}$

A Constituição Brasileira discriminou, de forma confusa e criticável, as competências das entidades federativas em diversos dispositivos, destacando-se os artigos $22,23,24,25$ e 30 . Esta exposição visa analisar a competência legislativa para editar normas gerais de Direito urbanístico. O objeto de estudo é, portanto, bem preciso: não se trata de analisar a teoria geral do Estado Federal, suas características, nem as peculiaridades do Estado Brasileiro, não se trata de analisar genericamente a discriminação constitucional de competências vigente no ordenamento, nem de analisar todas as competências legislativas ou administrativas de determinado ente federativo, não se trata, também, de analisar toda competência legiferante referente ao Direito urbanístico. Interessa aqui tão somente fixar os limites conceituais das normas gerais editadas em matéria de Direito urbanístico. ${ }^{4}$

A análise do conteúdo e alcance das normas gerais de Direito urbanístico exigirá um panorama das competências legislativas sobre essa disciplina. Esse panorama, todavia, restringir-ser-á ao necessário para os fins propostos. O tema das competências para edição de normas urbanísticas implicaria em vários desdobramentos que, conscientemente, foram deixados de lado. O panorama traçado será, tão somente, um instrumento para exata compreensão do significado das normas gerais de Direito urbanístico no sistema constitucional de divisão de competências legislativas.

princípios mais importantes são os da Federação e da República". ATALIBA, Geraldo. Competência legislativa supletiva estadual. Revista de Informação Legislativa, Brasília, ano 19, n. 73, jan./mar. 1982, p. 84. Fundamentava essa assertiva com uma série de argumentos, destacando-se o seguinte: "De todas essas considerações, é importante salientar que o princípio federal, em suas mais essenciais exigências, só pode ser revogado por força de uma verdadeira revolução, que deite por terra o texto constitucional e ab-rogue categoricamente todo o sistema, a partir de suas bases. Só arrasadora revolução popular pode anular o princípio federal". (p. 87).

2 Vale observar que, conforme doutrina a insigne Lúcia Valle Figueiredo, a Federação brasileira tem particularidade e anomalia que a difere do conceito técnico de federação: a particularidade está na inclusão do Município na Federação e a anomalia no fato de que o Município não tem representatividade no Poder Legislativo Central. FIGUEIREDO, Lúcia Valle. Competências administrativas dos Estados e Municípios - Licitações. Revista Trimestral de Direito Publico. São Paulo. n. 8, p.24-39, 1994, p. 25.

3 Pacífica a doutrina neste ponto: a discriminação das competências dos entes federativos numa Constituição rígida é característica essencial do Estado Federal. Nesse sentido: BANDEIRA DE MELLO, Oswaldo Aranha. Natureza Jurídica do Estado Federal. São Paulo: Prefeitura do Município de São Paulo, 1948, p. 72 et seq.; BARROSO, Luis Roberto. Direito Constitucional Brasileiro: o problema da Federação. Rio de Janeiro: Forense, 1982, p. 55 et seq.: ZIMMERMAN, Augusto. Teoria Geral do Federalismo Democrático. Rio de Janeiro: Lúmen Juris, 1999, p. 76-79.

4 Diante de tais objetivos, recomendável a lembrança da sempre oportuna lição de Oswaldo Aranha Bandeira de Mello: " na exposição de qualquer doutrina, parte-se de certos postulados e. apesar de serem suscetíveis de prova, esta deve ser tomada como já feita, sendo tais postulados no momento, recebidos como axiomas". (1948, p. 19). Trata-se de imperativo epistemológico de qualquer exame científico. 


\subsection{A competência concorrente da União e dos Estados para legislar sobre}

Direito urbanístico: artigo 24, I, da Constituição

A Constituição de 1988 atribui à União, aos Estados e ao Distrito Federal a competência para legislar concorrentemente sobre Direito urbanístico (artigo 24, I). No parágrafo primeiro do artigo 24 , no entanto, restringe a competência da União à edição de normas gerais; aos Estados e ao Distrito Federal, a contrario sensu, é dada a competência para editar normas específicas.

Por força do parágrafo segundo. caso a União edite as normas gerais, Estados e Distrito Federal possuem também competência suplementar, que conforme a doutrina de Lúcia Valle Figueiredo, consiste em "preencher claros, adicionar, esclarecer, aperfeiçoar". ${ }^{5}$ Podem, assim, estabelecer, para o seu âmbito territorial, normas gerais complementares às normas gerais editadas pela União ou regulamentar as normas gerais editadas por esta.

E, caso a União não exerça sua competência, possuem, nos termos do parágrafo terceiro, competência plena. A plenitude desta competência sofre, todavia, duas limitações: uma, qualitativa, posto que a Constituição acrescenta "para atender a suas peculiaridades", ou seja, o exercício da competência não pode exorbitar as peculiaridades ou interesses próprios do Estado em que foi editada; outra temporal, posto que tem suspensa sua eficácia, caso editada, posteriormente, norma geral federal com ela incompatível. ${ }^{6}$

5 FIGUEIREDO, Lúcia Valle. Competências administrativas dos Estados e Municípios - Licitações. Revista Trimestral de Direito Publico. São Paulo, n.8, 1994, p. 28. De fato, competência suplementar, aí, é equivalente à competência complementar, nada tendo a ver com a competência plena, estabelecida no parágrafo terceiro. Contra, considerando que a competência suplementar difere da complementar ou supletiva e equivale à plena prevista no parágrafo terceiro: LOBO, Paulo Luiz Neto. Competência Legislativa Concorrente dos Estados-Membros na Constituição de 1988. Revista de Informação Legislativa, Brasília, ano 26, n. 101, jan./mar. 1989, p. 98-99. Tércio Sampaio Ferraz Jr. concorda que a competência suplementar do $\$ 2^{\circ}$ não se confunde com a plena do $\$ 3^{\circ} \mathrm{e}$ esclarece: "a competência suplementar não é para a edição de legislação concorrente, mas para a edição de legislação decorrente, que é uma legislação de regulamentação, portanto de normas gerais que regulam situações já configuradas na legislação federal e às quais não se aplica o disposto no $\$ 4^{\circ}$ (ineficácia por superveniência de legislação federal), pois com elas não concorrem". FERRAZ JR., Tércio Sampaio. Normas Gerais e Competência Concorrente: uma exegese do art. 24 da Constituição Federal. Revista Trimestral de Direito Público, São Paulo, n.7, 1994. p. 19-20. Diverge-se, entretanto, do ilustre autor: os Estados e o Distrito Federal podem editar normas gerais, desde que compativeis com as editadas pela União, que não se limitem ao regulamento destas. Competência suplementar significa, assim. competência para editar normas gerais complementares e regulamentares das normas gerais editadas pela União.

6 Cf. FARIAS, Paulo José Leite. A federação como mecanismo de proteção ao meio ambiente. Revista de Informação Legislativa. Brasília, ano 34. $\mathrm{n}^{\circ}$ 135, jul./set. 1997. p. 286. Tércio Sampaio Ferraz Jr. explica, de forma lapidar, a competencia plena prevista no $\$ 3^{\circ}$ do art. 24 : "O $\$ 3^{\circ}$ regula o caso de inexistência de lei sobre normas gerais, ou seja, de lacuna. A Constituição Federal, ocorrendo a mencionada inexistência, autoriza o Estado federado a preenchê-la, isto é, a legislar 


\subsection{A doutrina de Geraldo Ataliba sobre normas gerais}

Ante o exposto, torna-se imprescindível para compreensão da competência legiferante federal em matéria de Direito urbanístico saber o exato significado conceitual de normas gerais. Juristas de escol tentaram decifrar o significado dessa expressão: o saudoso Prof. Geraldo Ataliba defendeu ardorosamente, a partir da interpretação do princípio federativo, quando da Constituição de 1967 (alterada pela E.C. $n^{\circ} 01 / 69$ ), que as normas gerais possuíam uma dupla finalidade: "a) preencher lacunas do texto constitucional e b) evitar, na medida do possível, por antecipação (ou preventivamente), os conflitos de competência entre as pessoas constitucionais". ' Apesar do brilhantismo da teoria, tudo indica que não foi acolhida pelo constituinte de $1988 .^{8}$

\subsection{A doutrina de Diogo Figueiredo Moreira Neto sobre normas gerais}

Diogo Figueiredo Moreira Neto também formulou teoria própria sobre o assunto: normas gerais são, para o administrativista, um tertium genius normativo, situadas entre o que ele denomina de normas-princípios e as normas particularizantes. Assim como os princípios, para o jurista, as normas gerais estabelecem diretrizes, orientações, linhas mestras e se situam, ambos, no plano das questões fundamentais, não admitindo particularizações. No entanto. se os princípios declaram um valor juridicamente protegido, conformam um padrão vinculatório para a norma particularizante e vedam ao legislador e aplicador de agirem em contrariedade ao valor neles declarado, as normas gerais, além de terem todas essas funções, distintamente dos princípios aplicam-se concreta e diretamente às relações e situações específicas no âmbito

sobre normas gerais, mas apenas para atender a suas peculiaridades. O Estado, assim, passa a exercer uma competência legisłativa plena, mas com função colmatadora de lacuna, vale dizer, apenas na medida necessária para exercer sua competência própria de legislar sobre normas particulares. Ele pode. pois, legislar sobre normas gerais naquilo em que elas constituem condições de possibilidade para a legislação própria sobre normas particulares. Tais normas gerais estaduais com função colmatadora por isso mesmo só podem ser gerais quanto ao conteúdo, mas não quanto ao destinatário: só obrigam nos limites da autonomia estadual". (1994, p. 19).

7 ATALIBA. Geraldo. Normas Gerais de Direito Financeiro e Tributário e autonomia dos Estados e Municípios. Revista de Direito Público. São Paulo, ano 3, v. 10, out./dez. de 1969, p. 63. E, a seguir, fixava como princípio hirto, a ser rigorosamente observado: "tudo que possa ser disciplinado por lei simplesmente federal (na esfera da União), estadual (na esfera do Estado) ou municipal (no âmbito do Município), sem manifesto e palpável perigo de atrito ou usurpação de competência alheia, não pode absolutamente ser objeto de norma geral." (p. 70).

8 A categoria das normas gerais não foi utilizada na Constituição de 1988 nos estritos limites defendidos por Geraldo Ataliba: primeiro, por força da clara redação das letras " a" e " $b$ " do inciso III do artigo 146; segundo, pelo extenso rol de matérias suscetíveis de regulação por normas gerais fixado no artigo 24. Se a interpretação do publicista adequava-se ao texto de 1967. não subsiste ao de 1988. Recomendável. assim, seguir sua própria lição e abandonar essa doutrina: "Se, como no caso presente (referindo-se às normas complementares), o Direito Positivo nāo acompanha rigorosamente os termos da construção científica e não guarda suficiente harmonia com suas exigências, é mais prudente - cautela obviadora de perplexidades e confusões - abandonar as categorias doutrinárias e extrair diretamente do sistema suas exatas consequêencias". (p. 62, esclarecimento nosso). 
de competência administrativa federal; aplicam-se concreta e diretamente às relações e situações específicas no âmbito da competência estadual ou municipal sempre que o Estado-membro ou o Município não haja exercitado sua competência concorrente particularizante ou haja exercido essa competência em contrariedade ao valor nelas declarado. Por outro lado, as normas gerais distinguem-se das normas particularizantes quanto ao valor jurídico, posto que naquelas, este é abstrata e diretamente referido; nestas, está intrinsecamente ligado à relação ou situação jurídica concretamente tutelada pela norma e nela definida: quanto ao destinatário, posto que a norma geral se dirige ao legislador estadual ou municipal, enquanto que a norma particularizante dirige-se ao agente que irá praticar o ato concreto e quanto à aplicação, posto que a geral conjuga eficácia indireta e direta, mediata e imediata e a particularizante é sempre direta e imediata. ${ }^{9}$

\section{$2.4 O$ conceito de princípios jurídicos}

Essa doutrina. sem desprestigiar o entendimento do nobre jurista, mostra-se, hoje, inadmissível. O conceito de princípio jurídico passou por três fases bem distintas na Teoria Geral do Direito. Na primeira fase aproximava-se do significado comum da palavra: princípios eram os fundamentos de uma dada disciplina jurídica, seus aspectos mais importantes. ${ }^{10}$

$\mathrm{Na}$ segunda fase princípios jurídicos adquirem significado técnico, deixam de ser todo assunto importante e geral e passam a ser determinados enunciados do direito positivo dotados de extraordinária importância para o entendimento de todo o sistema, diante da alta carga valorativa a eles atribuída. " Esse é o conceito adotado por Diogo Figueiredo Moreira Neto: princípios não são tomados como uma "expressão irredutível de manifestação do deôntico" 12 e por isso, para ele, "não se caracterizam imediatamente em relações e situações específicas da vida real" ${ }^{13}$,

9 MOREIRA NETO, Diogo Figueiredo. Competência concorrente limitada: o problema da conceituação das normas gerais. Revista de Infonnação Legislativa, Brasília, ano 28, n. 111 , jul./set. 1991, p. 150 et seq. A teoria foi integralmente adotada por Lúcia Valle Figueiredo. Competências administrativas dos Estados e Municípios - Licitações, p. 29-31.

10 Daí, por exemplo. o nome de obras célebres, como a de Oswaldo Aranha Bandeira de Mello e de Ruy Cirne Lima, nas quais os assuntos tratados correspondiam aos temas gerais, mais importantes do Direito Administrativo. BANDEIRA DE MELLO, Oswaldo Aranha. Princípios Gerais de Direito Administrativo. Rio de Janeiro: Forense, 1968, v. I: LIMA, Ruy Cirne. Princípios de Direito Administrativo Brasileiro. 3 ed. Porto Alegre: Sulina, 1954.

11 O conceito de Celso Antônio Bandeira de Mello representa magnificamente essa fase: "Princípio é por definição, mandamento nuclear de um sistema, verdadeiro alicerce dele, disposição fundamental que se irradia sobre diferentes normas compondo-lhes o espírito e servindo de critério para sua exata compreensão e inteligência exatamente por definir a lógica da racionalidade do sistema normativo, no que lhe confere a tônica e lhe dá sentido harmônico". BANDEIRA DE MELLO, Celso Antonio. Curso de Direito Administrativo. 13. ed. rev., atual e ampl. São Paulo: Malheiros, 2001, p. 771.

12 A expressão é Paulo de Barros Carvalho. Direito Tributário: fundamentos jurídicos da incidência. 2. ed. rev. São Paulo: Saraiva, 1999, p. 17.

13 NETO, 1988, p. 155. 
seriam enunciados normativos, mas não têm a estrutura de normas jurídicas pois deles não decorrem relações jurídicas disciplinadoras das condutas concretas.

Essa visão, ao menos nos dias de hoje, mostra-se insustentável. Vigora, na Teoria Geral do Direito, a terceira fase do conceito de princípios jurídicos: estes têm a estrutura qualitativa de normas jurídicas e podem. independente da edição de uma regra jurídica, regular as relações intersubjetivas. Tanto as regras quanto os princípios são normas jurídicas e, nesse sentido, passíveis de aplicação direta no mundo fenomênico. consistindo ambos em manifestações irredutíveis do deôntico. Sem embargo. possuem diferença estrutural: princípios são normas que ordenam que se realize algo na maior medida possível, são, nesse sentido, mandados de optimização realizáveis de acordo com as circunstâncias fáticas e jurídicas; regras são normas que exigem um cumprimento pleno, sendo somente cumpridas ou descumpridas, são, nesse sentido, determinações no campo das possibilidades fáticas e jurídicas. ${ }^{14}$ Fica afastada, com os avanços da Teoria Geral do Direito, a concepção de que as normas gerais são um terceiro gênero normativo na medida em que cai por terra a afirmação de que as normas gerais diferenciar-se-iam dos princípios pelo fato de caracterizarem imediatamente as relações da vida real. ${ }^{15}$ Necessária, assim, uma conceituação de normas gerais que atenda as concepções hoje vigorantes.

\subsection{Elemento formal do conceito de normas gerais}

Norberto Bobbio toma por base um critério formal de classificação das normas jurídicas, baseado exclusivamente na estrutura lógica das proposições. Toda norma

14 Os conceitos são de Robert Alexy. Princípios Jurídicos y Razón Práctica. In Derecho y Razón Práctica. 2. reimpr. corrig. México: Fontamara, 2002, p. 13-14. Essa nova fase sobre o conceito de princípios iniciou-se com Ronald Dworkin. Levando os Direitos à Sério. 1. ed. São Paulo: Martins Fontes, 2002. E consolidou-se com Alexy, principalmente a partir de sua obra-prima Teoria de los Derechos Fundamentales. Tradução de Ernesto Garzón Valdés. 1. ed., 2. reimpr. Madri: Centro de Estudios Políticos Y Constitucionales, 2002. O exame dessa moderna concepção sobre os princípios exige várias considerações que não cabem neste estudo. As referências sobre a teoria de Alexy dão-se apenas na medida necessária para explicação da teoria aqui defendida sobre as normas gerais. 15 Citam-se dois exemplos de aplicação direta dos princípios na vida real, independente da edição pelo legislados de uma regra intermediária: 1) O Conselho de Estado Francês considerou legítimo o ato do Prefeito de Morsang-sur-Orge, fundado na violação do princípio da dignidade da pessoa humana, de interditar o espetáculo de arremesso de anão. O caso é mencionado por Daniel Sarmento. A ponderação de interesses na Constituição Federal. 1. ed. 2 tir. Rio de Janeiro: Lumen Juris, 2002, p. 72. 2) Tornou-se comum no Brasil o proprietário de imóvel urbano alugar a um capataz para que este subloque a várias famílias, instituindo uma habitação coletiva. Ao pretender a retomada do imóvel, o proprietário ingressava com a ação de despejo em face do capataz e, por força do artigo 15 da Lei de Locações, via, com a rescisão do contrato principal, automaticamente rescindidas todas as sublocações empreendidas. Vigora, atualmente, o entendimento de que esse procedimento é proibido por força do princípio da função social dos contratos. Nesse caso. são descaracterizadas as sublocações e impedidas as rescisões automáticas. Esse entendimento fundamentou a edição do Provimento 9/97, de 9/5/1997, da Corregedoria Geral de Justiça do Estado de São Paulo que determina ao oficial de justiça, verificando tratar-se de habitação coletiva, dar ciência e identificar todos os ocupantes do imóvel. Vide Procedimento muda em habitação coletiva. Tribuna do Direito, São Paulo, ano 5, n. 51, jul. 1997, p. 20. 
jurídica possui, segundo o saudoso jurista, um destinatário-sujeito e um destinatário-objeto e tanto este como aquele podem apresentar-se sob a forma universal e sob a forma singular. Daí a existência de quatro tipos de normas: prescrições com destinatário universal, prescrições com destinatário singular, prescrições com ação universal, prescrições com ação singular. ${ }^{16}$ Assim, a categoria das normas gerais utilizada pelo constituinte brasileiro é, pela simples utilização do adjetivo, incompatível com duas categorias normativas: as prescrições com destinatário singular e com ação singular. Eis a primeira delimitação: normas gerais são, necessária e imperativamente, normas com destinatário universal e ação universal. Não é correto, no entanto, tomar qualquer norma com destinatário universal e ação universal como uma norma geral para os fins de delimitação da competência concorrente federal, ${ }^{17}$ além do elemento formal há também um elemento material, porém, de difícil caracterização.

\subsection{Elemento material do conceito de normas gerais}

Para compreensão do limite material do conceito de normas gerais, necessário examinar uma característica do federalismo só recentemente reconhecida: sua indissociável ligação com o conceito de democracia. O Federalismo implica na descentralização territorial do poder, fato que, em países de território extenso, é condição indispensável para o exercício da democracia. ${ }^{18} \mathrm{~A}$ descentralização territorial do

16 BOBBIO. Norberto. Teoria da Norma Jurídica. Tradução de Fernando Pavan Baptista e Ariani Bueno Sadatti. Apresentação de Alaôr Caffé Alves. 1. ed. Bauru: Edipro, 2001, p. 179.

17 Leonardo Greco defende exatamente o contrário: "A limitação da competência da União às normas gerais não significa que a legislação federal nessas matérias deva ater-se do nivel dos princípios e dos critérios, deixando a regulamentação dos institutos específicos à legislação estadual. Normas gerais são todas as normas emanadas da União, desde que aplicáveis uniformemente a todos os Estados e a todos os cidadãos, sem discriminações, ou seja, normas de aplicação isonômica em todo o território nacional. Tais normas podem dispor apenas sobre princípios ou descer a detalhes de regulamentação, desde que uniformes em todo o País, de acordo com a maior ou menor intervenção que a União queira exercer nessas matérias, deixando aos Estados maior ou menor autonomia". GRECO, Leonardo. Competências constitucionais em matéria ambiental. Revista dos Tribunais, São Paulo, ano 82, v. 687, jan. 1993, p. 27. Não é possível a adoção dessa posição, que retira do conceito de normas gerais qualquer conteúdo material. Cabe esclarecer, além disso, que normas gerais devem ser nacionais, ou seja, valer tanto para a União, quanto para os Estados, Municípios e Distrito Federal, mas isso não quer dizer que a norma geral não possa aplicar-se a apenas uma parte do território nacional. Nesse sentido, corretamente doutrina Paulo Affonso Leme Machado: "A norma geral federal ambiental, ou em outra matéria de competência concorrente. não precisa necessariamente abranger todo o território brasileiro. Uma norma geral ambiental federal poderá dispor, por exemplo, sobre as áreas previstas no art. $225, \$ 4^{\circ}$ - Floresta Amazônica Brasileira, Serra do Mar, Mata Atlântica, Pantanal e Zona Costeira. A norma geral pode abranger somente um ecossistema, uma bacia hidrográfica ou somente uma espécie vegetal ou animal". MACHADO, Paulo Affonso Leme. Direito Ambiental Brasileiro. 9. ed. rev., atual. e ampl. Sāo Paulo: Malheiros, 2001, p. 82.

18 A indissociável ligação entre federalismo e democracia é, hoje, pacificamente reconhecida pela doutrina. Jorge Miranda afirma: "Não menos relevante vem a ser a relação entre formas de Estado 
poder implica em poderes executivo e legislativo locais ou regionais e isso, evidentemente, facilita e muito o exercício da cidadania. Basta o exemplo brasileiro, país de enormes dimensões territoriais: um cidadão de um pequeno Município tem muito mais facilidade de influenciar o legislativo de seu Município do que o Congresso Nacional. Disso decorre uma consequiência fundamental: o exercício democrático do poder garante de forma muito mais efetiva o princípio da igualdade do que o exercício autoritário. Se as leis fossem produzidas apenas pelo Congresso Nacional, perceba-se, valeriam sempre para todo o território nacional e, na maioria das vezes, passariam por cima de idiossincrasias extremadas. Por impossibilidade fática. o legislador não poderia prever todas as diversidades que assolam o Brasil e ao igualar as condições de um cidadão residente no sul com um cidadão residente no norte, em muitas e muitas vezes, feriria drasticamente o princípio da igualdade. ${ }^{19} \mathrm{O}$ legislador local e regional ao atentar para as peculiaridades de sua localidade cumpre as exigências do princípio da igualdade: tratar desigualmente os desiguais na medida de sua desigualdade. A descentralização territorial do poder, em síntese. é. em países de territórios extensos e de acentuadas diversidades regionais e locais, uma imposição dos princípios democrático e da igualdade.

Os princípios democrático e da igualdade, no entanto, não podem ser levados até a última conseqüência por dois motivos. Pelo primeiro, o Estado Federal é uno, composto por entidades não soberanas, de modo que a exclusiva defesa dos interesses locais ou regionais inviabilizaria a sobrevivência da união. Daí a pertinência das competências privativas da União: proteger os interesses predominantemente nacionais ${ }^{20}$ e, com isso, a permanência da unidade federal. ${ }^{21}$ Esse primeiro fator de

e regimes políticos, realidades independentes só até certo ponto. Um poder autocrático é um poder fortemente centralizado: daí a subsistência apenas do Estado unitário ou a redução do federalismo a mera fachada. Um poder democrático e liberal propenderá a acolher a descentralização ou o federalismo: o federalismo é uma espécie de separação de poderes no âmbito territorial (C. $J$. Friedrich) e o mesmo talvez se possa dizer do regionalismo". Manual de Direito Constitucional: estrutura constitucional do Estado. 4. ed. rev. e atual. Coimbra: Coimbra Editora, 1998, Tomo III, p. 299. Nesse sentido, de forma mais enfática, vide MORBIDELLI, Janice Helena Ferreri. Um novo pacto federativo para o Brasil. São Paulo: Celso Bastos Editor, 1999, p. 44-51: ZIMMERMANN, 1999. p. $155-158$

19 A Federação brasileira, fruto da desagregação de um Estado unitário, sofre de uma criticável centralização do poder. A Uniāo detém a maior parte das competências legislativas, pouco restando dos Estados e Municípios e isso. muitas vezes. implica em sérias violaçōes do princípio da igualdade. Exemplo gritante é a legislação penal: há tịpos penás que são compatíveis com a região sul e sudeste e absolutamente incompatíveis com as demais e vice-versa. A consciência da antijuridicidade, por diferenças de costume e de desenvolvimento urbano, é bem distinta entre algumas regiões do país. Uma legislação penal que atentasse para essa diversidade só seria possível se a competência fosse estadual. o que tornaria mais efetivo o princípio da igualdade.

20 Segue-se aqui a clássica concepção de Hely Lopes Meirelles de que não existem interesses exclusivamente federais. estaduais ou municipais, mas interesses predominantemente nacionais, predominantemente estaduais ou predominantemente municipais. MEIRELLES, Hely Lopes. Direito Municipal Brasileiro. 11 ed. São Paulo: Malheiros. 2000. p. 131.

21 A competência privativa da Uniāo deve obedecer ao princípio da subsidiariedade: só deve caber à União o estritamente indispensável ao asseguramento dos interesses predominantemente nacio- 
importância da legislação federal, a tutela dos interesses predominantemente nacionais, imprescindível para manutenção do vínculo, justifica, portanto, as competências privativas. O segundo fator é a garantia do princípio da segurança jurídica, justificante das competências concorrentes da União. Esse fator é bem caracterizado através do exemplo brasileiro: como a Federação brasileira possui mais de três mil municípios. se cada Município tivesse uma legislação processual, penal, civil totalmente diferente, a segurança jurídica dos cidadãos brasileiros estaria absolutamente comprometida. Uma legislação processual diversa, por exemplo, implicaria menos no enfraquecimento do vínculo federativo do que na ofensa ao princípio da segurança jurídica. ${ }^{22}$ Finalmente, conforme a precisa conclusão de Tércio Sampaio Ferraz Jr.: é a garantia da segurança jurídica que justifica a instituição em favor da União do poder legiferante para edição de normas gerais. ${ }^{23} \mathrm{Em}$ síntese, dois fatores justificam a legislação federal numa Federação: o primeiro, garantia dos interesses predominantemente nacionais, fundamenta a instituição de competências privativas; o segundo, garantia da segurança jurídica, fundamenta a possibilidade de edição de normas gerais.

$\mathrm{Na}$ base das competências concorrentes enunciadas no artigo 24 da Constituição estão dois princípios constitucionais: o princípio da igualdade, justificante da edição de normas particulares pelos Estados conforme suas peculiaridades, e o princípio da segurança jurídica, justificante da edição de normas gerais pela União, de caráter nacional, aplicáveis, em princípio, a todos os entes federativos. O constituinte concebeu essa divisão de competências vislumbrando a necessidade de concretizar esses dois importantes princípios jurídicos. ${ }^{24}$ Essa é, aliás, uma característica própria dos

nais, só o que não for possível deixar aos Estados e aos Municípios. Sobre o princípio da subsidiariedade, vide o importante trabalho de BARACHO. José Alfredo de Oliveira. O princípio da subsidiariedade: conceito e evolução. Rio de Janeiro: Forense, 2000.

22 A insegurança tornar-se-ia evidente: basta imaginar a existência de mais de três mil Códigos de Processo, com disciplina recursal absolutamente distinta. Pode-se ir mais adiante: imaginem-se três mil prazos distintos de contestação ou de interposição de apelação.

23 O raciocínio do jurista é lapidar: "Por certeza entende-se a determinação permanente dos efeitos que o ordenamento jurídico atribui a um dado comportamento, de modo que o cidadão saiba ou possa saber de antemão a consequiência das suas próprias açōes. Ora, esta exigência vem satisfeita ao máximo quando o legislador não abandona a regulação dos comportamentos ao ajuizamento de caso por caso pelo aplicador, mas estabelece com uma norma a regulação de uma ação-tipo, de modo que nela caibam todas as ações concretas que ela inclui. A tipificação. nesse sentido. é garantia da certeza que é base da segurança jurídica. Mas a segurança só se obtém se, além da regulação de uma ação tipo, esta valer para todos igualmente. A igualdade é um atributo da segurança que diz respeito não ao conteúdo, mas ao destinatário das norınas, garantindo segurança à norma que obedece ao princípio da isonomia." FERRAZ JR. Tércio Sampaio. Segurança Jurídica e normas gerais tributárias. Revista de Direito Tributário. São Paulo, ano 5, n. 17/18, 1981, p. 51, grifo do autor. Como afirmado, normas gerais são necessariamente normas com destinatário universal e com ação universal. Ressalta-se, no entanto. como defendido acima, ao contrário do aparentemente afirmado pelo insigne jusfilósofo, que nem sempre as normas ditas gerais concretizam o princípio da igualdade. A divergência, no entanto, conforme demonstrado à seguir. é apenas aparente.

24 Isso foi brilhantemente captado por Tércio Sampaio Ferraz Jr. O autor, ao analisar as competências tributárias, assim ponderou: "Quando se enfatiza a certeza, a segurança se torna tributária 
princípios: estarem em constante colisão. Ao contrário das regras, afirmam Dworkin e Alexy, apresentam, diante do caso concreto, diferentes pesos, dimensões ou importâncias. Daí a diferença de aplicação: as regras se aplicam mediante subsunção, os princípios, mediante ponderação. Num conflito entre duas regras, há contradição entre ambas: ou uma é tomada como exceção da outra, caso em que permanecem ambas no sistema, ou é tomada como inválida e retirada do sistema, aplicando-se. nos dois casos, apenas uma das regras. Num conflito entre princípios, há tensão e não contradição entre ambos: diante das circunstâncias do caso concreto um é mais aplicado do que o outro. São as circunstâncias que ditam o peso do princípio e a medida de sua aplicação, podendo ocorrer que um afaste totalmente o outro ou apenas parcialmente num determinado caso e ocorra exatamente o inverso em outro, tudo dependendo da ponderação efetuada. ${ }^{25}$ Quem efetua essa ponderação, observa-se, é o aplicador do princípio. E o aplicador dos princípios constitucionais da segurança jurídica e da igualdade. num primeiro momento, é o próprio legislador infraconstitucional. ${ }^{26}$ Este, ao editar uma lei, aplica os princípios constitucionais em constante colisão e, consequientemente, é obrigado a efetuar uma ponderação. O legislador federal tem também diante de si um caso concreto: trata-se da respectiva lei a ser editada, referente à determinada matéria. em um contexto histórico determinado. Diante dessas circunstâncias que tem diante de si, deve efetuar uma ponderação e analisar qual princípio tem maior peso: o princípio da igualdade ou o princípio da

de um poder centralizador que garante a uniformidade dos conteúdos do vértice para a base do sistema. Quando se enfatiza a isonomia. a segurança será tributária de uma maior liberdade de conteúdos, exigindo-se apenas a correta uniformidade na discriminação das competências, favorecendo, pois, a livre iniciativa". (1981, p. 52). E. a seguir, do examinar as duas interpretaçōes sobre a abrangência da competência prevista no artigo 146 da Constituição, doutrina que uma interpretação menos restritiva funda-se na função-certeza e uma interpretação mais restritiva. tal como a defendida por Ataliba, funda-se na função-igualdade. Percebe-se, nesse passo, a congruência do pensamento do autor com a teoria aqui exposta: ao se ampliar a possibilidade de edição de normas gerais tributárias pela União valoriza-se a função-certeza em detrimento da função-igualdade; ao restringir essa possibilidade dá-se o contrário, valoriza-se a função-igualdade em detrimento da função-certeza. (1981, p. 54).

25 Sobre a ponderação de princípios vide DWORKIN, 2002, p. 35 et seq.: ALEXY, Sistema jurídico, princípios jurídicos y razón prática, p. 9 et seq.: Derechos, razonamiento jurídico y discurso racional. Derecho y razón práctica. 1. ed. 2. reimpr. corrig. México: Fontamara. 2002, p. 35 et seq. SARMENTO, 2002, p.97 et seq.: STEINMETZ, Wilson Antônio. Colisão de Direitos Fundamentais e princípio da proporcionalidade. Porto Alegre: Livraria do Advogado, 2001, p. 120 et seq.

26 Daí o brilho das palavras do eminente Geraldo Ataliba: "O primeiro - lógica e cronologicamente - intérprete da Constituição é o legislador que. no texto magno, vai buscar a fonte de sua competência. e necessariamente seus contornos, mas principalmente o sentido, a direção que deve imprimir à sua obra de criação legislativa. Este primeiro intérprete não pode - no meditar sobre a exegese do sistema a que deve dar animação, pela açāo legislativa - desatender ou desprezar o sentido apontado pelos princípios, nem as instâncias postuladas por suas exigências. (...) Dessarte, a interpretação das disposições constitucionais concernentes às competências da União há de considerar as decorrências desses magnos princípios, atentos os intérpretes para a harmonia do sistema, que postula a necessidade de combinação harmônica das diversas exigências concomitantemente incidentes sobre uma só situação". (1982. p. 88). 
segurança jurídica. Se concluir que, diante da matéria a ser legislada e naquele contexto histórico, o princípio da segurança jurídica tem maior peso que o princípio da igualdade, estará legitimado para editar uma norma geral. Se a ponderação por ele efetuada levar a resultado contrário, ou seja, que em relação a respectiva matéria o princípio da igualdade tem maior peso, não terá competência para editar normas gerais.

As normas gerais, assim, não possuem um conteúdo material preciso, previamente fixado pelo texto constitucional. Cada matéria suscitada deve ser examinada pelo legislador federal e submetida à ponderação que leve em conta todas as circunstâncias fáticas e jurídicas, devendo considerar, por exemplo, o momento histórico, as aspirações sociais, a incidência do princípio da igualdade. Dessa ponderação o legislador concluirá qual princípio constitucional apresenta maior peso e qual é afastado e em que medida é afastado. O resultado da ponderação dá com precisão os limites materiais do poder legiferante federal para editar normas gerais. Estas poderão ou não ser editadas, poderão ser mais ou menos minuciosas, tudo dependerá da dimensão do princípio da segurança jurídica diante das circunstâncias fáticas e jurídicas envolvidas.

Observa-se que a competência atribuída ao legislador federal não pode ser transformada por este num cheque em branco. É o legislador federal que deve efetuar a ponderação e apurar se tem ou não competência para editar normas gerais. Editadas estas, no entanto, passível a revisão pelo Poder Judiciário. No controle difuso ou concentrado de constitucionalidade o Poder Judiciário deverá efetuar uma nova ponderação e se, analisando a questão, concluir que o princípio da igualdade tem maior peso nas circunstâncias que o princípio da segurança jurídica, deverá declarar inconstitucional a lei federal por vício de competência. Imperiosa uma ressalva: em face do princípio da separação dos poderes, no entanto, o Poder Judiciário só estará legitimado a afastar a ponderação efetuada pelo legislador caso não haja dúvidas em relação ao erro desta ponderação. Os critérios preconizados não são de livre arbítrio do juiz: o magistrado que se propõe a modificar a ponderação legislativa deve levar em consideração padrões importantes que se opõem à mudança, tais como o "princípio da supremacia do Poder Legislativo" ${ }^{27}$. Ao modificar a ponderação efetuada pelo legislador, o juiz empreende uma ponderação entre os princípios que justificam a manutenção daquela e os princípios que exigem sua mudança. Em síntese, se o Judiciário, ao efetuar nova ponderação em sede de controle de constitucionalidade, concluir que o princípio da igualdade tem maior peso que o princípio da segurança jurídica e que o princípio da supremacia do Legislativo, deve afastar a ponderação

27 A expressão é de DWORKIN, 2002, p. 60. Precisa ser devidamente entendida: o princípio da supremacia do Legislativo, aqui, não significa que este esteja em posição hierárquica superior aos demais poderes e sim que existe, por força do princípio da separação dos poderes previsto no artigo $2^{\circ}$ da Constituição, uma carga valorativa maior à ponderação efetuada pelo legislador. Para que o Judiciário reveja essa ponderação, deve atentar para incidência, além dos princípios jurídicos que deveriam inicialmente ser considerados pelo legislador, do princípio da supremacia que favorece a permanência desta. 
legislativa efetuada e considerar a norma geral inconstitucional por vício de competência.

\subsection{As normas gerais de Direito urbanístico e as competências privaivas dos Estados e Municípios}

As limitações de ordem formal e material até aqui analisadas dão o significado da expressão normas gerais constante do $\S 1^{\circ}$ do artigo 24 do Texto Maior. Interessa aqui ir além: precisar o alcance das normas gerais de Direito urbanístico. Em relação a estas, além desses dois limites, há muito mais a se considerar: o legislador federal, ao editar normas gerais de Direito urbanístico, além de se ater a comandos com destinatário e ação universais e observar o resultado de uma ponderação entre os princípios da segurança jurídica e da igualdade, deve, necessariamente, atentar para as competências privativas em matéria de Direito urbanístico atribuídas às demais entidades federativas: os Estados possuem competência privativa para instituição de regiões metropolitanas e aglomerações urbanas e microrregiões, nos termos do artigo $25, \S 3^{\circ}$ e os Municípios, competência privativa para legislar sobre assuntos de predominante interesse local, nos termos do artigo 30 . inciso $I,{ }^{28}$ e, conseqüentemente, para editar o plano diretor, nos termos do artigo $182, \S 1^{\circ}$ da Corstituição.

As normas gerais editadas pela União, assim, em matéria urbanística, além de obedecerem aos limites formais e materiais fixados, não devem tratar das matérias atribuidas privativamente aos Estados e aos Municípios. Conforme a seguir verificado, entretanto, a competência municipal em matéria urbanística, no complexo sistema traçado pelo constituinte, não é propriamente privativa.

\subsection{As três espécies de normas gerais federais de Direito urbanístico}

O entendimento das normas gerais de Direito urbanístico, de fato, ao contrário das normas gerais em geral, apresenta-se muito mais complexo. Isso porque a disciplina da competência legiferante de Direito urbanístico não se esgota no artigo 24, I da Constituição. Segundo José Afonso da Silva, o Direito urbanístico objetivo consiste no "conjunto de normas jurídicas reguladoras da atividade do poder público destinada a ordenar os espaços habitáveis".29 As normas de Direito urbanístico têm por objeto, assim, disciplinar a ordenação do território.

Fixado esse conceito, observa-se, primeiramente, a existência de três tipos de normas gerais federais de Direito urbanístico: 1) as normas gerais editadas com base no $\S 1^{\circ}$ do artigo 24 , que podem ser regulamentadas e complementadas pelos

28 É praticamente pacífico o entendimento de que a competência para legislar sobre assuntos de interesse local, atribuída aos Municípios pelo inciso I do artigo 30 é privativa. Por todos: FERRARI, Regina M. Macedo Nery. Competência Legislativa do Município. Cadernos de Direito Constitucional e Ciência Política, São Paulo, ano 1, n. 1, out./dez. 1992, p.262.

29 SILVA, José Afonso da. Direito urbanístico Brasileiro. 2. ed. rev. e atual., 2. tir. São Paulo: Malheiros, 1997, p. 31. 
Estados e Distrito Federal no exercício da competência suplementar prevista no §2 ou, no caso de omissão da União, por estes editadas para atendimento de suas peculiaridades, no exercício da competência plena prevista no $\S 3^{\circ}-$ normas gerais federais de Direito urbanístico fruto da competência concorrente com os Estados e Distrito Federal; 2) as normas gerais editadas com base no artigo $21, \mathrm{XX}^{30}$, que não são passíveis de serem editadas, nem regulamentadas, nem complementadas por outra entidade federativa - normas gerais federais de Direito urbanístico fruto da competência privativa da União; 3 ) e as normas gerais editadas com base no artigo 182. que podem ser regulamentadas e complementadas pelos Municípios ou, no caso de omissão pela União, por estes editadas para atendimento de suas peculiaridades - normas gerais federais de Direito urbanístico fruto da competência concorrente com os Municipios. ${ }^{31}$

\subsection{A competência concorrente da União e dos Municípios para editar normas de Direito urbanístico diretamente vinculadas ao interesse local}

Necessário para precisar o âmbito de abrangência das normas gerais federais de Direito urbanístico, examinar, ainda que sucintamente, a competência municipal. Os Municípios, nos termos do artigo 30, VIII, possuem competência para promoção do adequado ordenamento territorial, mediante planejamento e controle do uso, do parcelamento e da ocupação do solo urbano. ${ }^{32}$ Essa competência esta intimamente relacionada com o disposto no artigo 182: aos Municípios compete executar a política de desenvolvimento urbano.

Sobre essa competência cabem duas ordens de considerações. Primeiramente, trata-se, em larga medida, de interesse predominantemente local e, nesse sentido, seria privativa do Município. Ocorre que o constituinte optou por criar uma exceção ao artigo 30, I, no que se refere ao Direito urbanístico: a questão urbanística de

$30 \mathrm{O}$ artigo 21, XX, da CF atribui à União competência privativa para instituir diretrizes para o desenvolvimento urbano, inclusive habitação, saneamento básico e transporte coletivo. Não há como, tecnicamente, diferenciar as normas gerais das diretrizes: diretrizes são normas gerais. A Professora Lúcia Valle Figueiredo vislumbrou a existência de normas gerais privativas da União ao comentar o inciso XXI do artigo 22. FIGUEIREDO, Lúcia Valle. Competências administrativas dos Estados e Municípios - Licitações, p. 29.

31 O artigo 182 confere ao Município a competência para executar a política do desenvolvimento urbano. Condicionou-a, no entanto. às diretrizes fixadas em lei, entenda-se. federal. Trata-se de competência concorrente, similar à prevista no artigo 24 : nos mesmos moldes do $\$ 1^{\circ}$ do artigo 24 , a competência da União restringe-se à edição de normas gerais, sinônimo de diretrizes, e a competência dos Municípios, a editar normas específicas. Aplicam-se também o regramento dos $\$ \$ 2^{\circ}$ e $3^{\circ}$ do artigo 24 : o Município pode complementar ou regulamentar as normas gerais editadas pela União e, no caso de omissão, o Município tem competência plena para atender suas peculiaridades.

32 Segundo José Afonso da Silva. apesar da expressāo "no que couber", não se trata apenas de competência complementar, suplementar ou supletiva, mas própria do Município. Nesse sentido. SILVA. 1997. p. 55. Não se trata, no entanto, conforme será exposto, de simples competência privativa. 
interesse local não é privativa dos Municípios, mas de competência concorrente entre estes e a União. Os Municípios, no que se refere ao interesse local, tem competência para editar normas urbanísticas específicas e a União, competência para editar diretrizes (tomadas aqui como sinônimo de normas gerais). Sendo competência de natureza concorrente, aplicam-se as regras dos $\S \S$ do artigo 24: o Município pode suplementar ou complementar as normas gerais federais, bem como editá-las, em caso de omissão pela União, para atendimento de seu interesse local.

\subsection{Normas gerais de Direito urbanistico de primeiro nível}

Restaria dar funcionalidade ao artigo 24, I, daí a segunda ordem de considerações: a competência prevista no artigo 30 , VIII, além de estar vinculada ao artigo 30, I (interesse local) e ao artigo 182, está vinculada ao Direito urbanístico (art. 24, I). Por força disso. para o Direito urbanístico, o constituinte previu a instituição de um complexo conjunto normativo de diferentes amplitudes. Primeiramente, ao editar as normas gerais previstas no $\$ 1^{\circ}$ do artigo 24 , o legislador federal tem que, na ponderação efetuada entre os princípios da igualdade e da segurança jurídica, atentar para uma carga valorativa em favor do princípio da igualdade, abstrata e previamente estabelecida pelo sistema constitucional, decorrente da imposição de que os interesses predominantemente locais sejam deixados ao encargo municipal. Por força da necessidade de observância dos artigos 30 , VIII e 182, fundados na necessidade de se deixar o interesse local ao encargo dos Municípios, o princípio da igualdade, em matéria urbanística, possui uma prioridade prima facie. ${ }^{33}$ Essa prioridade garante que o conteúdo das normas gerais editadas não esteja diretamente vinculado ao interesse local. Disso decorre que as normas gerais federais de Direito urbanístico. fundadas no $\S 1^{\circ}$ do artigo 24 devem ser, por imposição do sistema, muito mais gerais do que as demais normas gerais. Podem, por isso, ser denominadas de normas gerais de Direito urbanístico de primeiro nível.

\subsection{Normas gerais de Direito urbanistico de segundo nivel}

O legislador estadual, ao editar as normas específicas de Direito urbanístico, fundadas no artigo 24 , I combinado, a contrario sensu, com o artigo $24, \S 1^{\circ}$, também deve fazer, evidentemente, uma ponderação. Continua, para o legislador estadual, nesse segundo momento (ou primeiro, se estiver exercitando a competência plena prevista no $\S 3^{\circ}$ ), a necessidade de observar a imposição constitucional de que seja deixado aos Municípios o poder de disciplinar os assuntos de interesse local.

As normas editadas pelo legislador estadual, perceba-se, também se fundam numa oposição entre o princípio da igualdade, que agora leva em conta no âmbito

33 A expressão é de Alexy. Sistema Jurídico, Princípios Jurídicos y Razón Práctica, p. 19. Note-se que o constituinte quando da promulgação da Constituição também efetuou ponderações que devem ser respeitadas. Daí as prioridades que certos princípios constitucionais têm na ponderação a ser efetuada pelo legislador ordinário. 
regional as diferenças locais, e o princípio da segurança jurídica. Uma norma urbanística válida para todo Estado pode trazer mais segurança, mas atentar contra as peculiaridades de determinadas localidades. Se há necessidade de ponderação para apurar se uma norma urbanística deve valer para todo território nacional ou só para o território regional, também há necessidade de ponderação para apurar se uma norma urbanística deve valer para todo território regional ou somente para o local. A essa ponderação aplica-se tudo que foi afirmado para a ponderação exercida pelo legislador federal, sendo, assim, passível de revisão pelo judiciário.

Há também, aqui, uma prioridade prima facie do princípio da igualdade, em face dos artigos 30, VIII e 182, fundados na competência assegurada aos Municípios de disciplinar os assuntos de interesse local. Aqui também, portanto, há a garantia de que o conteúdo das normas editadas pelo Estado não esteja diretamente vinculado ao interesse local. Por força disso, as normas específicas editadas pelos Estados com fundamento no artigo 24 , I, ao contrário do que ocorre nas demais matérias arroladas nesse dispositivo, não são propriamente normas específicas. Trata-se de normas gerais, mais especificas do que as editadas pela União, mas gerais em relação às editadas pelos Municípios. Podem ser denominadas aqui de normas gerais de Direito urbanístico de segundo nível. ${ }^{34}$

\subsection{Panorama geral das competências legiferantes urbanísticas}

O cenário traçado, apesar de complexo, dá a exata dimensão das normas gerais federais de Direito urbanístico. Num primeiro momento, por força do $\S 1^{\circ}$ do artigo 24. o legislador da União deve efetuar uma ponderação entre o princípio da segurança jurídica e o princípio da igualdade e apurar se, diante das circunstâncias, tem competência para editar uma norma geral federal urbanística. Há, no entanto, uma prioridade prima facie do princípio da igualdade, em face das competências atribuídas pelo constituinte ao Município. Concluindo que o princípio da segurança exige a edição de uma norma urbanística nacional, válida para todo território brasileiro, está, na exata medida em que essa exigência afaste o princípio da igualdade, este abstratamente fortalecido pelo próprio constituinte, legitimado a editar uma norma geral de Direito urbanístico, aqui denominada "de primeiro nível".

Com a edição dessa norma, por força da competência concorrente prevista $a$ contrario sensu no artigo $24, \S 1^{\circ}$, o legislador estadual deve efetuar uma nova

34 Nesse sentido afirmou o Ministro Carlos Veloso do C. Supremo Tribunal Federal na ADIn 478-6 — SP, por este relatada, D. J. 28.02.1997: "Esta última faculdade conferida aos Municípios, que diz respeito ao planejamento e controle do uso, do parcelamento e da ocupação do solo urbano, para o adequado ordenamento territorial (CF, art. 30. VIII), põe-se no campo do interesse local, ao que me parece. Não obstante, relaciona-se com o Direito urbanístico, pelo que está sujeito a normas federais e estaduais (CF, art. 24, I). (...) Uma e outra competência, já falamos, sujeitam-se a normas de entidades políticas outras: a do inc. IV, do art. 30, à legislação federal; a do inc. VIII do art. 30 , a normas estaduais e federais (C. F., art. 24, I). Estas normas, entretanto, deverão ser gerais, em forma de princípios, sob pena de tornar inócua a competência municipal, que constitui exercício da capacidade autônoma dos municípios. A interpretação sistemática da Constituição impõe tal conclusāo". 
ponderação entre os princípios da segurança jurídica e o da igualdade e apurar, se diante das circunstâncias, tem competência para editar uma norma geral regional urbanística. Também aqui vigora uma prioridade do princípio da igualdade. decorrente da determinação constitucional de que seja deixado ao Município o poder de legislar sobre o interesse local. Concluindo que o princípio da segurança exige a edição de uma norma urbanística regional, válida para todo território do respectivo Estado, está, na exata medida em que essa exigência afaste o fortalecido princípio da igualdade, legitimado a editar uma norma geral de Direito urbanístico, aqui denominada "de segundo nível" 35

Até aqui, por força da prioridade prima facie atribuída ao princípio da igualdade nas ponderações efetuadas, o conteúdo das normas gerais federais e estaduais editadas não terá direta vinculação com o interesse local. As normas gerais de Direito urbanístico de primeiro e segundo nível, decorrentes do artigo 24 , I, da Constituição Federal, não tratam de matérias diretamente vinculadas ao interesse local.

Num terceiro momento, editadas com base no art. 24, I, essas normas gerais de Direito urbanístico, passa-se à ordenação direta dos espaços habitáveis, matéria diretamente vinculada ao interesse municipal. Pela regra do artigo 30, I, a matéria seria de competência privativa dos Municípios. $\mathrm{O}$ constituinte optou por abrir uma exceção: instituiu uma competência concorrente entre a União e os Municípios, conforme se extrai do artigo 182 intrinsecamente ligado ao artigo 30, VIII. O legislador da União deve, aqui também, efetuar uma ponderação entre os princípios da segurança e da igualdade e concluir se e em que medida aquele afasta este e autoriza a edição de uma norma geral federal (diretriz) sobre a política de desenvolvimento urbano, assunto diretamente vinculado ao interesse local. Sempre que, neste nível, a ponderação não autorizar o afastamento do princípio da igualdade, a norma a ser editada será tão somente da competência do Município. No caso de omissão da União, seja na edição das normas gerais previstas no $§ 1^{\circ}$ do art. 24 . seja na edição das diretrizes previstas no art. 182, ou dos Estados, seja na edição de normas gerais de segundo nível $\left(24, \S 2^{\circ}\right)$ ou também na de primeiro nível $\left(24, \S 3^{\circ}\right)$, o Município terá competência plena para promover o adequado ordenamento territorial e executar a política de desenvolvimento urbano. ${ }^{36}$ Caso exercidas as respectivas competências pela União e pelo Estado, deverá respeitar as normas gerais editadas, podendo, sempre, complementá-las ou regulamentá-las (30, II).

\section{Conclusões}

1 A redação das letras "a" e "b" do inciso III do artigo 146 da Constituição bem como o extenso rol do artigo 24 deixam claro que o constituinte não acolheu,

35 Lembra-se que os Estados e o Distrito podem editar normas gerais de primeiro nível (no caso de omissāo da União, desde que adstritas às suas peculiaridades), regulamentá-las ou complementá-las por força das competências suplementar e plena previstas nos $\$ \S 2^{\circ}$ e $3^{\circ}$ do art. 24 . Desde é claro, que observado o processo de ponderação aqui fixado.

36 A omissão dos Estados e da União em editar as normas gerais de Direito urbanístico não pode inibir a competência municipal de zelar pelo interesse local. 
em relação a categoria das normas gerais, a doutrina restritiva de Geraldo Ataliba. Por outro lado, a doutrina do terceiro gênero normativo de Diogo Figueiredo Moreira Neto, ao tomar como elemento de diferenciação entre as normas gerais e os princípios a impossibilidade destes, ao contrário daquelas, de regerem diretamente as relações específicas da vida, mostra-se incompatível com as modernas teorias sobre os princípios jurídicos e, portanto, insustentável.

2 Por força disso se tornou imperiosa a elaboração de uma teoria sobre o conceito de normas gerais, compatível com o texto constitucional e com os avanços da Teoria Geral do Direito. Conclui-se que estas possuem um elemento formal: por força do próprio adjetivo empregado em sua denominação são, necessariamente, prescrições com destinatário e ação universais. Esse elemento, no entanto, foi considerado insuficiente para conceituação das normas gerais, afastando-se a doutrina formalista de Leonardo Greco.

3 Além do elemento formal, as normas gerais possuem um elemento material. Para compreensão deste, examinou-se a íntima ligação entre o federalismo e a democracia. Em territórios extensos, os princípios democráticos e da igualdade exigem a produção de normas regionais e locais observantes das idiossincrasias existentes. Esses princípios, no entanto, não podem ser levados até as últimas consequiências por força de dois fatores justificantes da legislação federal: o primeiro, a garantia dos interesses predominantemente nacionais, fundamenta a competência privativa da União; o segundo, a garantia da segurança jurídica, fundamenta a competência da União para edição de normas gerais.

4 A competência concorrente, concluiu-se, funda-se num constante conflito, vislumbrado pelo constituinte, entre os princípios da segurança jurídica e da igualdade. O primeiro exige uma legislação uniforme em todo território nacional, independente das diversidades regionais e locais, o segundo exige que a legislação trate desigualmente os desiguais na medida de sua desigualdade e, assim, leis regionais e locais que atentem para essas diferenças. É encargo do legislador infraconstitucional efetuar uma ponderação entre esses princípios e, diante das circunstâncias, da respectiva matéria a ser legislada, do contexto histórico, das expectativas sociais, apurar qual princípio tem maior peso. Se concluir que para a respectiva matéria o princípio da segurança jurídica tem maior peso, estará legitimado a editar uma norma geral.

5 A ponderação efetuada pelo legislador pode ser, como visto, revista pelo Poder Judiciário que, no controle concentrado ou difuso de constitucionalidade, deve efetuar uma nova ponderação. Nesta, no entanto, há uma diferença: devem ser levados em consideração, além dos princípios que deveriam inicialmente ser considerados pelo legislador, o princípio, decorrente da separação de poderes, da prevalência da ponderação do legislador. Por força desse princípio, somente se houver certeza quanto ao erro da ponderação efetuada pelo legislador estará o judiciário autorizado a modificá-la e, em consequêencia, a considerar a lei inconstitucional por vício de competência.

6 As normas gerais, concluiu-se, não possuem um elemento material preciso, previamente fixado. Cada matéria a ser legislada deve ser examinada pelo legislador federal e submetida à ponderação. Esta indicará, com precisão, se e em que medida 
o princípio da igualdade é afastado pelo princípio da segurança jurídica. As normas gerais poderão ou não ser editadas, poderão ser mais ou menos minuciosas, tudo dependerá do peso do princípio da segurança jurídica diante das circunstâncias fáticas e jurídicas.

7 Apurou-se, na seqüência, que as normas gerais de Direito urbanístico, além de possuírem os elementos formal e material fixados, não podem tratar das matérias atribuídas privativamente aos Estados e aos Municípios. A competência privativa dos Estados para legislador sobre Direito urbanístico decorre do artigo $25, \S 3^{\circ}$ da Constituição. Os Municípios têm, por força do artigo 30, I, competência privativa para legislar sobre assuntos de interesse local. A competência municipal, no entanto, não é privativa e cria, em relação às normas gerais de Direito urbanístico, uma série de particularidades, tornando a matéria demasiadamente complexa.

8 Diferenciou-se três categorias de normas gerais federais urbanísticas: 1) as normas gerais federais de Direito urbanístico, fruto da competência concorrente com os Estados e Distrito Federal prevista no artigo 24 , inciso I e $\S 1^{\circ} ; 2$ ) as normas gerais federais de Direito urbanístico fruto da competência privativa da União prevista no artigo $21, \mathrm{XX} ; 3$ ) as normas gerais federais de Direito urbanístico, fruto da competência concorrente com os Municípios prevista no artigo 182. Na primeira categoria, os Estados e o Distrito Federal podem complementar ou regulamentar as normas gerais editadas pela União (competência suplementar) e, em caso de omissão desta, editá-las para atender suas peculiaridades (competência plena). Na terceira categoria isso se dá com os Municípios, ou seja, estes podem complementar ou regulamentar as normas editadas pela União e, em caso de omissão, editá-las para atender suas peculiaridades. Na segunda categoria, as normas gerais não comportam regulamentação nem complementação pelos demais entes federativos e, em caso de omissão da União, não poderão ser editadas por estes.

9 Por força das competências atribuídas aos Municípios nos artigos 30, VIII e 182, fundadas na intenção constituinte de deixar ao encargo destes a disciplina do interesse local, a competência concorrente da União e dos Estados, fixada no artigo 24, I, sofre profunda alteração: instituiu-se um complexo normativo de diferentes amplitudes. Por força das competências municipais há uma prioridade prima facie do princípio da igualdade na ponderação efetuada pelo legislador federal e isso faz das normas gerais de Direito urbanístico editadas por ele muito mais gerais do que as demais normas gerais. Daí a denominação: normas gerais de Direito urbanístico de primeiro nível. O legislador estadual, após serem editadas as normas gerais de primeiro nível pelo federal ou, em caso de omissão, no exercício da competência plena, não tem competência para editar normas propriamente particulares. Deve também observar a previsão das competências municipais e, por força disso, efetuar uma segunda ponderação entre o princípio da segurança jurídica e o princípio da igualdade, este também aqui reforçado por uma prioridade prima facie. As normas editadas pelo legislador estadual não são particulares, mas normas gerais de Direito urbanístico de segundo nível. $\mathrm{Na}$ primeira ponderação, efetuada pelo legislaủor federal. o princípio da segurança jurídica exige a edição de normas urbanísticas válidas para todo território brasileiro; na segunda ponderação, efetuada pelo legis- 
lador estadual, o princípio da segurança exige a edição de normas urbanísticas válidas para todo território do respectivo Estado.

10 Após a edição das normas gerais de Direito urbanístico de primeiro e segundo nível, passa-se à ordenação direta dos espaços habitáveis, matéria diretamente vinculada ao interesse local. Por força do artigo 30. I, essa disciplina seria de competência privativa do Município. O constituinte, no entanto, preferiu instituir uma exceção: por força do artigo 182, preceito vinculado ao artigo 30 , VIII, a competência para promoção da política urbana é de competência concorrente da União e dos Municípios, em que àquela cabe a edição de diretrizes, sinônimo de normas gerais, e a estes cabe a edição de normas específicas. O legislador federal, também aqui, deve efetuar uma ponderação entre os princípios da segurança jurídica e da igualdade e apurar se a exigência de edição de uma norma de Direito urbanístico referente à ordenação da política urbana. assunto diretamente vinculado ao interesse local, válida para todo território brasileiro, prepondera. Sempre que nessa ponderação não se justificar o afastamento do princípio da igualdade, a competência para editar a norma será exclusivamente do Município. Este, ao exercer sua competência, deve respeitar todas as normas gerais editadas pela União e pelos Estados.

11 Por fim, observou-se que, em caso de omissão da União na edição das normas gerais de primeiro nível $\left(21\right.$, I e $\left.\S 1^{\circ}\right)$, ou na edição das normas gerais vinculadas ao interesse local (182), ou dos Estado na edição de normas gerais de primeiro ou segundo nível $\left(21\right.$, I e $\S \S 1^{\circ}, 2^{\circ}$ e $\left.3^{\circ}\right)$, o Município terá competência plena para disciplinar o interesse local, promovendo o adequado ordenamento de seu território e a política de seu desenvolvimento urbano. Além disso, exercidas aquelas competências pela União e pelos Estados sempre terá competência suplementar (30, II), podendo complementar ou regulamentar as normas gerais por eles editadas.

\section{Referências Bibliográficas}

ALEXY, Robert. Princípios Jurídicos y Razón Práctica. In Derecho y Razón Práctica. 2. reimpr. corrig. México: Fontamara, 2002, p. 7-24.

Derechos, razonamiento jurídico y discurso racional. Derecho y razón práctica. 1. ed. 2. reimpr. corrig. México: Fontamara, 2002, p. 25-41.

Teoria de los Derechos Fundamentales. Tradução de Ernesto Garzón Valdés. 1. ed., 2. reimpr. Madri: Centro de Estudios Políticos Y Constitucionales, 2002.

ATALIBA, Geraldo. Competência legislativa supletiva estadual. Revista de Informação Legislativa, Brasília, ano 19, n. 73, jan./mar. 1982, p. 81-94.

Normas Gerais de Direito Financeiro e Tributário e autonomia dos Estados e Municípios. Revista de Direito Público, São Paulo, ano 3, v. 10, out./dez. de 1969. p. 44-80.

BANDEIRA DE MELLO, Oswaldo Aranha. Princípios Gerais de Direito Administrativo. Rio de Janeiro: Forense, 1968, v. I.

Natureza Jurídica do Estado Federal. São Paulo: Prefeitura do Município de São Paulo, 1948. 
BANDEIRA DE MELLO, Celso Antonio. Curso de Direito Administrativo. 13. ed. rev., atual e ampl. São Paulo: Malheiros, 2001.

BARACHO, José Alfredo de Oliveira. O princípio da subsidiariedade: conceito e evolução. Rio de Janeiro: Forense, 2000.

BARROSO. Luis Roberto. Direito Constitucional Brasileiro: o problema da Federação. Rio de Janeiro: Forense, 1982.

BOBBIO, Norberto. Teoria da Norma Jurídica. Tradução de Fernando Pavan Baptista e Ariani Bueno Sadatti. Apresentação de Alaôr Caffé Alves. 1. ed. Bauru: Edipro, 2001.

CANOTILHO, J. J. Gomes. Direito Constitucional e Teoria da Constituição. $4^{\circ} \mathrm{ed.}$, Coimbra: Almedina, 2000.

CARVALHO, Paulo de Barros. Direito Tributário: fundamentos jurídicos da incidência. 2. ed. rev. São Paulo: Saraiva, 1999.

DWORKIN, Ronald. Levando os Direitos à Sério. 1. ed. São Paulo: Martins Fontes, 2002.

FARIAS, Paulo José Leite. A federação como mecanismo de proteção ao meio ambiente. Revista de Informação Legislativa, Brasília, ano $34, \mathrm{n}^{\circ} 135$, jul./set. 1997, p. 283-300.

FERRARI, Regina M. Macedo Nery. Competência Legislativa do Município. Cadernos de Direito Constitucional e Ciência Política, São Paulo, ano 1, n. 1, out./dez. 1992, p. 258-265.

FERRAZ JR., Tércio Sampaio. Normas Gerais e Competência Concorrente: uma exegese do art. 24 da Constituição Federal. Revista Trimestral de Direito Público, São Paulo, n.7, 1994, p. 16-20.

Segurança Jurídica e normas gerais tributárias. Revista de Direito Tributário, São Paulo, ano 5, n. 17/18, 1981, p. 51-56.

FIGUEIREDO, Lúcia Valle. Competências administrativas dos Estados e Municípios - Licitações. Revista Trimestral de Direito Publico. São Paulo, n.8, 1994, p.24-39.

GRECO, Leonardo. Competências constitucionais em matéria ambiental. Revista dos Tribunais, São Paulo, ano 82, v. 687, jan. 1993, p. 23-33.

LIMA, Ruy Cirne. Principios de Direito Administrativo Brasileiro. 3 ed. Porto Alegre: Sulina, 1954.

LOBO, Paulo Luiz Neto. Competência Legislativa Concorrente dos Estados-Membros na Constituição de 1988. Revista de Informação Legislativa, Brasília, ano 26, n. 101, jan./mar. 1989, p. 87-104.

MACHADO, Paulo Affonso Leme. Direito Ambiental Brasileiro. 9. ed. rev., atual. e ampl. São Paulo: Malheiros, 2001.

MEIRELLES, Hely Lopes. Direito Municipal Brasileiro. 11 ed. São Paulo: Malheiros. 2000.

MIRANDA, Jorge. Manula de Direito Constitucional: estrutura constitucional do Estado. 4. ed. rev. e atual. Coimbra: Coimbra Editora, 1998, Tomo III.

MORBIDELLI, Janice Helena Ferreri. Um novo pacto federativo para o Brasil. São Paulo: Celso Bastos Editor, 1999. 
MOREIRA NETO, Diogo Figueiredo. Competência concorrente limitada: o problema da conceituação das normas gerais. Revista de Informação Legislativa, Brasília, ano 28, n. 111, jul./set. 1991, p. 127-162.

SARMENTO, Daniel. A ponderação de interesses na Constituição Federal. 1. ed. 2 tir. Rio de Janeiro: Lumen Juris, 2002.

SILVA, José Afonso da. Direito urbanístico Brasileiro. 2. ed. rev. e atual., 2. tir. São Paulo: Malheiros, 1997.

STEINMETZ, Wilson Antônio. Colisão de Direitos Fundamentais e princípio da proporcionalidade. Porto Alegre: Livraria do Advogado, 2001.

TRIBUNA DO DIREITO. Procedimento muda em habitação coletiva. São Paulo, ano 5, n. 51, jul. 1997, p. 20.

ZIMMERMAN, Augusto. Teoria Geral do Federalismo Democrático. Rio de Janeiro: Lúmen Juris, 1999. 
Abuso do Direito nos Contratos de Consumo

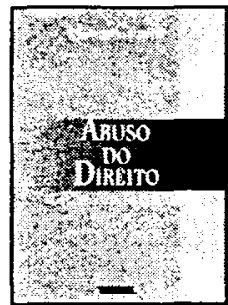

Heloisa Carpena

Ref. 0344

Brochura

271 págs.

Form. $14 \times 21$

2001

ISBN 85-7147-290-4

Esta obra compreende o estudo do abuso do direito, desde as origens do instituto até sua aplicação pelos tribunais brasileiros. A teoria do ato abusivo é analisada como fenômeno de relativização dos direitos subjetivos, que passam a ser funcionalizados de acordo com os princípios que regem e fundamentam o ordenamento jurídico, dentre eles, 0 da dignidade da pessoa humana.

\section{A Responsabilidade Civil do Fornecedor de Produtos pelos Riscos do Desenvolvimento}

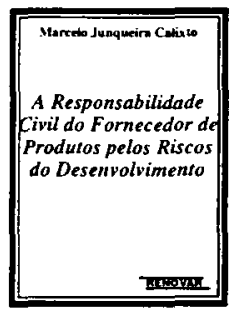

Marcelo Junqueira Calixto

Ref. 507

Brochura

278 págs.

Form. $13,5 \times 21$

2004

ISBN 85-7147-451-6

São analisados aqui os conceitos fornecidos pelo Código de Detesa do Consumidor e os pressupostos da responsabilidade do fornecedor, quais sejam, o defeito do produto, o dano e o nexo causal entre defeito e dano. Passando ao estudo das excludentes de responsabilidade, a dissertaçāo encontra o seu tema central no exame de uma possivel excludente, aquela fundada nos chamados riscos do desenvolvimento
O Abuso do Direito e as Relaçōes Contratuais

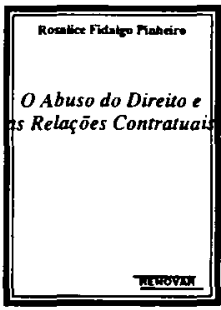

Rosalice Fidalgo Pinheiro

Ref. 0402

Brochura

464 págs.

Form. $13,5 \times 21$

2002

ISBN 85-7147-835-X

Ao fixar sua análise no campo das relações contratuais, a autora identifica na autonomia privada e no direito subjetivo cristalizados em torno de interesses individuais os elementos de base para o desenvolvimento do abuso do direito. A percepção da doutrina, no que se refere à dificuldade de uma definição atual do abuso do direito, serve-Ihe de impulso para que examine, criticamente, a metodologia clássica do direito privado.

\section{O Direito do Consumidor na Era da Globalização A descoberta da cidadania}

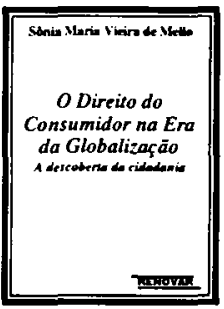

Sonnia Maria Vieira de Mello

Ret. 0180

Brochura

172 págs.

Form. 13,5×21

1998

ISBN 85-7147-088-X

Neste livro, a autora expõe como o consumidor, nesta era de produção global, torna-se consideraveimente vulnerável diante das práticas perpetuadas pelos fornecedores de bens e serviços, muito mais bem informados, fundamentados e assessorados, para os embates mercadológicos. Por fim, analisa as perspectivas que se abrem aos consumidores no Mercosul e em nivel internacional. 